\title{
Research Methods in Taxation History
}

\author{
By \\ Jane Frecknall-Hughes
}

Professor of Accounting and Taxation

Hull University Business School, Cottingham Road, Hull, HU6 7RX, UK

E-mail: J.Frecknall-Hughes@ hull.ac.uk

DOI:10.1561/105.00000041/ http://dx.doi.org/10.1561/105.00000041 


\title{
Research Methods in Taxation History
}

\begin{abstract}
This paper is an attempt to consider the research methods used in taxation history, which is an area that has attracted increased academic interest in recent years. The paper looks at the various routes that may provide an entry into studying taxation generally and at the inherently interdisciplinary/multidisciplinary nature of the subject. If taxation is researched through different disciplinary lenses, the focus of research changes, which brings to the forefront questions about the most appropriate research methods to use - questions which become more complex when taxation history is considered, along with fact that the different disciplines have their own histories which may themselves impact on taxation history research. The paper looks in detail at social science research methods, also legal research (as 'different' from other social science disciplines to which taxation is linked), as well as history and legal history, to evaluate research methods used in those areas. It shows that tax history can be researched in several ways from different perspectives, which show an underlying rigour and more similarity than is at first apparent.
\end{abstract}




\section{Research Methods in Taxation History}

\section{Introduction}

The purpose of this paper is to shed some light on the possible method(s) that may be used to study taxation history. Although it has been contended that people and governments do not learn anything from history (Hegel, 1830), ${ }^{1}$ nevertheless, examining tax history is useful if only to shed light on how tax law has become so complex over the years, which is an increasing problem worldwide. It is certainly a considerable issue for the UK, which "[i]t is generally acknowledged... has one of the most complicated tax systems in the world" (Aitken, 2010, p. 14). In recent years there has been a growing interest in research into various aspects of taxation history. For example, there is a biennial 'History of Tax' Conference organised by the Centre for Tax Law at the University of Cambridge and in 2013 there was an Inaugural Meeting of the Australasian Tax History Chapter at Queensland University of Technology Business School. However, there is little explication of research methodology/methods for tax history ${ }^{2}-$ and it is rare for tax history researchers to be explicit about their methodology/methods. This area may well be near-virgin territory and the time seems right for some consideration of tax history research methods/methodology.

The paper is developed as follows. Section 2 considers the approach to taxation research generally and the nature of taxation as a multidisciplinary or interdisciplinary subject, primarily in terms of social science methodology and methods; Section 3 considers legal research - relevant because modern taxation has its roots in law; Section 4 considers specific methodology/methods issues raised by tax history; Section 5 considers history research generally and also legal history research, which is beset by problems similar to those affecting tax history research; and Section 6 offers conclusions to the paper.

\footnotetext{
1 Frecknall-Hughes (2014, p. 88) points to the UK government's implementation of the 1980 Community Charge, which was a poll tax, as an example of this. She asks whether "a government fully conversant with the deep unpopularity of poll taxes in the past in England [would] ever have considered introducing another one ... but this is exactly what happened". The implications of tax history in terms of human behaviour and reaction are complex and under-researched.

${ }^{2}$ See, for example, McDonald, 2002; Frecknall-Hughes, 2012.
} 


\section{The approach to tax research}

Frequently an individual's perspective on taxation will be coloured or conditioned by the route via which he or she came to study taxation. As taxation is often regarded as a 'specialist' option within what might be termed academic 'base' disciplines, ${ }^{3}$ such as law, accounting, economics, psychology, etc., a student of taxation will usually commence his/her studies from a particular, pre-conditioned perspective. Typically, the approach to studying taxation might be as shown in Figure 1. One could replace 'accounting' in Figure 1, with another academic discipline (amending the rest of the figure accordingly).

\section{[Insert Figure 1 here]}

A researcher coming to tax research may thus be inclined towards using the research methods predominantly adopted for research in the base academic discipline where his/her initial studies of taxation commenced. However, because of its links to more than one academic discipline, taxation is widely recognised as an inherently multidisciplinary or interdisciplinary area of study (see Lamb et al., 2004, passim):

"Taxation is not a discipline in its own right, but a social phenomenon that can be studied through various disciplinary lenses. Commonly, taxation attracts researchers from the disciplines of law, accounting economics, political science, psychology and philosophy. These disciplinary backgrounds are each understandably narrow, and, in spite of researchers being no doubt experts in their fields, it can be challenging to apply their skills and knowledge to the complexities of research problems that emanate from the study of taxation."

McKerchar, 2008, pp. 5-6

Although many of the subjects referred to above are in the broader social sciences or humanities area (as opposed to pure sciences), looking at taxation through different disciplinary lenses nevertheless changes the focus of research. Instead of considering taxation from, say, an accounting perspective, with one 'leg' or 'arm' into taxation, taxation becomes central with 'arms' or 'legs' reaching into different disciplines, as per Figure 2.

\footnotetext{
${ }^{3}$ In UK university undergraduate programmes, taxation is often most commonly studied as a Level 3 (i.e., final year) optional subject. There are specialist undergraduate degrees in taxation, but these remain relatively rare, as do specialist masters' degrees.
} 


\section{[Insert Figure 2 here]}

Thus researchers in taxation may not be equipped to get to grips very easily with the elements added by other subject areas, especially in terms of research methods. How would an economics tax researcher cope, for example, if he/she found that a lot of the material he/she needed to consider on a particular topic was located (as can happen) in academic law journals?

There are now several works explicitly acknowledging the multidisciplinary and interdisciplinary nature of taxation (see Lamb et al., 2004, for law, accounting, political science and social policy) accompanied by an increasing interest in research approaches (methodology, methods and forms of analysis) that may be appropriate in a multidisciplinary and interdisciplinary context (see McKerchar, 2008; 2010; and Oats, 2012a). These show how taxation research can employ what might be termed 'the full range' of research approaches in social sciences, from the positivist to the interpretivist and the quantitative to the qualitative with much in between, such as critical realism and pragmatism (see McKerchar, 2008, pp. 7-8). Typically, quantitative methods use experiments and surveys to collect data and qualitative methods employ ethnography, case study, narrative, phenomenology, grounded theory, action research, etc., either singly or in a mixed method approach (see McKerchar, 2008, p. 14; Saunders et al., 2012, p. 128 and pp. 164-168). ${ }^{4}$ Rather annoyingly, the study of the area of research methodology is bedevilled by different meanings attached to the various terms used, which will affect taxation no less than any other area. A useful summary is provided by the "research onion" of Saunders et al. (2009, p. 108) shown in Figure 3. ${ }^{5}$ Saunders et al. have regularly revisited their "research onion" and the 2012 (sixth) edition of their book likewise includes pragmatism and realism (comprised for them of "direct realism" and "critical realism") in "research philosophies" (2012, p. 128), although earlier editions did not.

\section{[Insert Figure 3 here]}

\footnotetext{
${ }^{4}$ McKerchar (2008, p. 20) also refers to an extreme of "methodological anarchism", where there are no rules and " 'anything goes" ".

${ }^{5}$ The terminology used by Saunders et al. $(2009 ; 2012)$ is adopted by and large in this paper.
} 
McKerchar (2008, p. 8):

"[a] critical realist seeks to answer both the 'how' and 'why' questions. In terms of the underlying ontology, a critical realist sees greater complexity in the relationships under study, going beyond the depths of empirical realism. Researchers who subscribe to this paradigm would typically allow the research design to be driven by what was wanted to be learnt, rather than to be preordained. A pragmatist has a similar approach and freely chooses the methods, techniques and procedures that best meet the needs and purposes of the research".

In their 2012 "research onion", Saunders et al. also include, for the first time, "abductive" in 'research approaches'. This is an approach which "moves back and forth, in effect combining deduction and induction" (Saunders et al., 2012, p. 147).

Saunders et al. (2009), as McKerchar (2008), see the research paradigms (i.e., positivist and interpretivist) more as different points on a continuum, although it is common to find them described as "philosophically opposed" (see McKerchar, 2008, p. 7).

Although it is possible to use different research approaches in taxation research, often a particular approach becomes ossified, if not fossilised, within a particular discipline. Oats (2012b, p. 242) for example, comments on this in relation to accounting:

"In 2010 Hanlon and Heitzman ${ }^{6}$ published a paper that purports to present a review of tax research in accounting, as well as economics and finance, to the extent that they overlap with accounting ... While acknowledging that tax research emerges in different disciplines with different perspectives, the authors nonetheless proceed to describe tax research in accounting as being exclusively in the positivist domain, without any recognition that alternatives are available. This is curious, because within accounting research generally, while the positivist mainstream maintains its hegemony, most particularly in North America, there is nonetheless a clearly defined and well respected alternative strand of scholarship that embraces interpretivism in all its various guises".

The same is true to an even greater extent in finance (Oats, 2012b, p. 243).

\footnotetext{
${ }^{6}$ Hanlon, M., \& Heitzman, S. (2010). A review of tax research. Journal of Accounting and Economics, $50(2), 127-178$.
} 


\section{Specific issues in legal research}

As most modern - and much historical - taxation has its roots in law, one cannot consider tax history research without also considering legal research methods. Legal history research methods are also relevant (although tax history research need not be confined to these aspects, as stated earlier). Legal research is often considered as being rather different from other areas to which tax is related, but this need not be the case as will emerge from the following discussion.

McKerchar (2008, p. 18) comments that "[1]egal research has somewhat lagged behind quantitative and qualitative research when it comes to philosophical paradigms and acceptable conceptual frameworks". She cites the explanation of Salter and Mason $^{7}$ that legal research is often mistakenly construed as being about process and skills, such as identifying case law and statutes, rather than being "about the methodology or different approaches by which the objectives and goals of the researcher can be addressed". There seems to be a large number of practicallydirected works dedicated to advising a researcher how to find material (e.g., Mersky \& Dunn, 2002; Knowles \& Thomas, 2006), or research a legal case as for court argument/presentation (e.g., Cohen \& Olson, 2007). However, there is more theoretical material directed towards a research process (Chatterjee, 2000; McConville \& Chui, 2007; Morris \& Murphy, 2011), some of which (e.g., Pendleton, 2007) is similar to that in wider social science research and which will be discussed later. McKerchar (2008, p. 18) also cites the opinion of Hutchinson ${ }^{8}$ that any underlying research paradigm in legal research is often "unarticulated", and the result may thus be dysfunctional. However, she also suggests $(2008$, p. 8) that law research could be anywhere on the continuum referred to above:

"It could be positivist and employ a quantitative methodology based on empirical evidence - for example, how often has the law changed this century, how often has a particular section been the subject of a legal dispute, how long are various sections, or how easy is a piece of legislation to read? In contrast, it could be interpretivist and based on social construct - for example, what impact has the introduction of a baby bonus has on fertility rates in Australia? ... Critical realism or pragmatism may well offer a more comfortable paradigm

\footnotetext{
${ }^{7}$ Salter, M., \& Mason, J. (2007). Writing Law Dissertations. Harlow, Essex: Pearson Education Ltd.

${ }^{8}$ Hutchinson, T. (2005). Researching and Writing in Law, $2^{\text {nd }}$ edn. Sydney: Thomson.
} 
fit for legal researchers than either of the two extremes of positivism and interpretivism".

She goes on to suggest (2008, p. 8) that legal research may be posited as a different paradigm altogether, for example socio-legal studies.

McKerchar (2010, p. 15) comments that, while legal research may reflect "either positivism or non-positivitism", its methodological approaches basically comprise either doctrinal research, or non-doctrinal research. Doctrinal research "is typically based on the 'black letter' (or literal) analysis of formal rules and legal principles. It tends to rely on a distinctly deductive form of legal reasoning".

"The methodology of doctrinal research is appropriate where the aim of the research is to determine the meaning of a particular legal provision in accordance with the philosophy of legal positivitism. This type of research may or may not include hypotheses (consistent with deductive reasoning), but in this case the hypotheses are more akin to propositions than the hypotheses that typify quantitative research, and therefore can be accepted or rejected in accordance with empirical investigation."

McKerchar, 2010, p. 115

McKerchar (2010, p. 115) goes on to comment that this approach is typified by narrowness and does not address any societal or policy implications of law - and in terms of taxation could not address any economic, moral or equity issues. Nondoctrinal research, in the form of socio-legal studies, for example, may do so, as this type of legal study is " 'about law' rather than 'in law' and employs the methodologies commonly used in other disciplines" - and this is indicative of a "softening of traditional boundaries" (McKerchar, 2010, p. 116). This echoes the comments of Bradney (1998), who also remarks on the narrowness inherent in the doctrinal approach to law (especially in teaching), suggesting that this should be used not solely but alongside other methods used in the humanities and social sciences in "a broader attempt to understand law" (p. 72). He further suggests (p. 83) that law itself should be regarded as an interdisciplinary subject, citing Cartan \& Vilkinas (1990) that " "law is a living entity, which has a future as well as a present ... [and is] an evolving process with important element of history, sociology, politics and 
economics" "9 Socio-legal studies allow for a wider engagement in research (Bradney, 1998, pp. 83-84). Freedman (2004, p. 14) concurs that it is now "important to go beyond pure black-letter law", but legal scholars should have a good, legal technical knowledge as this is what marks out their work as legal research if they "adopt the concepts and methods from other disciplines".

\section{Turning to tax history}

How then is this all relevant to research into taxation history? It will be noted that Figure 2 shows taxation with an 'arm' or 'leg' reaching down into history. Taxation is an area which also has a rich, varied and extensive history of international dimensions, and as remarked earlier, is attracting an increasing amount of interest from researchers.

The historical aspect of taxation is unusual in methodological terms. It is possible to research tax history - itself an under-researched area - purely as one would research any other aspect of history, for example, the reign of King John and Magna Carta or the Tudor dynasty. One might look at the history of income tax, for instance, purely as a subject of study in its own right. This is the approach that Figure 2 inherently suggests. However, as taxation itself is multidisciplinary, the study of its history will - or arguably, should - of necessity also reflect the other disciplines to which it is related. Hence the lawyer, economist or psychologist who researches tax history will almost inevitably consider that history from their subject perspective, but may miss much if, say, the political, social or other dimensions are overlooked. Taxation is thus not just multidisciplinary as a subject, but multi-layered (or multidimensional and multifaceted) when one considers the history underlying those related subject areas.

Figure 2 thus needs to be amended to reflect this.

\section{[Insert Figure 4 here]}

This may have considerable implications for the research methods adopted when any tax history topic is researched. Will researchers examining tax history within their

${ }^{9}$ Cartan, G., \& Vilkinas, T. (1990). Legal literacy for managers: The role of the educator. The Law Teacher, 24(3), 246-257 (citing note 48 on p. 248). 
base disciplines be aware of and build into their research robust historical research methods as well as or instead of the methods more usually found within their discipline, as well as taking account of those in the related subject area(s), for example, law, as used in Figure 4? Can the different kinds of research methods be combined? Is tax history tax with a history focus or history with a tax focus? Is tax history the same as legal history (or does any of this matter)? If so, the method(s) for researching tax history could become very complex indeed. First of all, however, it is necessary to examine research methodology and methods in history.

\title{
5. History research ${ }^{10}$
}

There are many works that exist on research methodology/methods in history and historical theory. ${ }^{11}$ This is acknowledged by Gunn \& Faire (2012), but they go on to comment that there is (p. 5) "uncertainty among many historians about what exactly 'methods' mean or amount to in historical research". For example, in relation to history researchers' use of archives, they note (p. 5) the following.

\begin{abstract}
"Obviously, they are searching out and examining documents and other primary sources, but how they actually work on these sources is shrouded in mystery. Historical training routinely includes introduction to archives and sources; for some it may include palaeography or language training in order to be able to decipher primary texts generated in other time-periods and societies. But it is rare to find any explicit discussion of what choices may be made in the archive, what strategies pursued or how different types of sources might be interpreted. It is assumed that these skills will be absorbed by students or historians through a form of immersion, time and practice providing eventual mastery. Despite the burgeoning interest in the history of the archive over the last decade, there has been remarkably little discussion of the actual processes of archival research, or of what the historian and theorist Michel de Certeau termed the 'historiographical operation' by which the 'past', or its documentary traces, are turned into 'history' defined as a specific form of writing".
\end{abstract}

Black \& MacCraild (2000) suggest that, rather than studying the theoretical foundation of their subject, historians tend to reach for the facts. This may be the

\footnotetext{
${ }^{10}$ This section draws heavily on work considering tax history research in the context of legal history research, viz., see Frecknall-Hughes, J. (2012). Re-examining King John and Magna Carta: Reflections on Reasons, Methodology and Methods. In A. Musson \& C. Stebbings (Eds.). Making Legal History: Approaches and Methodology (pp. 244-263). Cambridge: Cambridge University Press.

${ }^{11}$ Rather confusingly, 'historiography' is the term used for historical research methods and the actual writing of history itself.
} 
result of a complicated discourse between philosophy, especially epistemology, and methodology, which can easily deter researchers. Cantor \& Schneider (1967, p. 9), make the concept of historical research more accessible:

"... history is unique among social and political disciplines in that it has no particular jargon or mysterious mathematical method. All the methodological principles of the historian are derived from common sense and are as much within the intellectual capacity of a freshman at a junior college as of a professor at Oxford”.

They recommend a "critical attitude" in which:

"the life of history resides, because the active, intellectual, searching quality that characterizes the best history writing, the striving for ideas that is the mark of the greatest historians, always is the result of an attempt to re-examine older ideas, to seek new meaning in old (and new) facts, to achieve a new hypothesis and a further understanding that will be a partial contribution to the long-range growth and development and change in historical understanding. This process will never cease, nor should it; the whole notion of an absolutely 'definitive' history of any subject is completely contrary to the recognition that the aim of historical investigation is understanding, and that understanding is inferential".

Cantor \& Schneider, 1967, p. 29

The historian must be able to assess the accuracy and validity of primary sources, by constantly querying and evaluating them, and when reading secondary (or even tertiary sources), read them for the points of view they express, for the inferences drawn from linking facts, and be especially aware of them as products of their own time (ibid.). A history researcher must also be aware of 'schools' or 'theories' of history and its overall purpose and nature (Fulbrook, 2002), as well as the interpretive bias(es) he/she might bring to bear. This is not unfamiliar ground to anyone, really, who has done serious research in any subject area. The primary difference from tax research undertaken from a history perspective would seem to be that of focus, not process. Indeed, there is already some financial/economic history research which follows methods which would be more familiar to mainstream economists - see, for example, Rutterford et al. (2009). Economics is an area which has had a strong history tradition for a long time. 
As stated earlier, there is little written specifically about methodology/methods in tax history. Much the same was true until recently also of legal history. As a result of the 19th British Legal History Conference, 'Making Legal History: Methodologies, Sources and Substance', held at the University of Exeter, 8-11 July 2009, a book was produced entitled Making Legal History: Approaches and Methodologies, edited by Anthony Musson and Chantal Stebbings, which addressed this lacuna. Comments by some of the authors show, perhaps, that legal history too has lagged behind other areas in terms of methodological considerations. Key features of the book are the emphasis on source materials, but there is emphasis on interpretation (Rabban, 2012), methodological debate (Senn, 2012) and interdisciplinary approaches (FrecknallHughes, 2012). The pre-eminent legal historian, Sir John Baker, comments in the first chapter on 'doing' legal history:

"After due reflection, I have come to the conclusion that I have no easily describable method, perhaps no method at all apart from the indulgence of curiosity. My main thesis here is that there may be some merit in this".

Baker, 2012, p. 7

He continues:

"... there are a number of approaches to consider. One might simply read what others have written and pick holes in it - there are always holes in anything. This is a rather negative method, but one which suits some temperaments well and is not devoid of value. It is more effective when coupled with some positive suggestions for setting the story straight. A second approach might be to pose some fundamental question about law and society, law and economics, or law and something else, or even just law, and then set off to see what can be found by way of a possible answer. This is a more beguiling method, but quite a risky one, because is may be that there is no evidence - or insufficient evidence on which to base an answer worth considering - in which case there is a temptation to fill in the gaps with speculation".

Baker, 2012, p. 7

There is nothing wrong with speculation (provided it is acknowledged as such), but it is not research and it does not answer any questions posed. The above comment suggests that legal history too is inherently interdisciplinary.

Sir John's third method (possibly owing something to an interest in archaeology): 
"has been to delve into the available sources first and see what kinds of question they raise or might answer ... I have benefited from the freedom to collect material at random over along period of years, stuffing notebooks and wearing out many pencils, until it became necessary to introduce finding aids to my own notes".

Baker, 2012, pp. 7-8

It is not unduly difficult to frame any of Sir John's approaches in terms of the "research onion" - and the approach adopted by Frecknall-Hughes (2012) in her chapter on 'Re-examining King John and Magna Carta: Reflections on Reasons, Methodology and Methods', which is focused on tax history does precisely this effectively combining Sir John's first and second methods. The chapter puts forward the thesis that Magna Carta was the outcome of a tax revolt by the barons, which was given weight when relevant secondary literature was examined. The theory was developed by looking at the creation of 'add-ons' by King John, creation of new taxes, increases in rate and frequency and opportunistic behaviour, through a series of inductive/deductive loops, with reference to Magna Carta itself for further support. This in turn generated a further theory, that 25 barons (named in Clause 61) who agreed to act as suretors for the king's promises made in the Magna Carta, would be likely to have had their own fiscal grievances which led to them being willing to undertake this task. Figure 5 shows the process.

\section{[Insert Figure 5 here]}

By reference to the "research onion" above, the path is as follows:

$\begin{array}{ll}\text { Research philosophy } & \text { Realism (critical) } \\ \text { Research approach } & \text { Deductive and Inductive (now referred to by } \\ & \text { Saunders et al. (2012, p. 128) as "abductive"), } \\ & \text { therefore } \\ & \text { Combined inductive and deductive loop } \\ \text { Research strategy } & \text { (grounded theory is a very specific example of } \\ & \text { this type of approach) } \\ \text { Choices } & \text { Mono method (data collection from source } \\ & \text { materials, qualitatively analysed) }\end{array}$


Time horizons

Data collection and analysis
Longitudinal (study over a number of years, namely John's reign)

See as per 'choices'. Source materials are both secondary and primary.

A critical realism approach was suitable to seek answers to 'how' and 'why' events might have happened. Therefore a combined inductive-deductive process was indicated. An inductive approach requires analysis of data; formulation of theory (i.e., generated from data/observation); an attempt to understand how humans interpret the social world, with less concern with generalisation of the results found; and an iterative process, with the stages proceeding in parallel. A deductive approach, on the other hand, requires generation of a hypothesis based on theory; an investigation which will test this hypothesis (to provide evidence on whether it is true or false); and an examination of the results of the investigation and modification of the theory if necessary.

It would not appear that research into history and law, with reference to taxation and Magna Carta required different paradigms or processes beyond the "research onion". Indeed, there is already some work which utilises other aspects of this, even in taxation work. McDonald (2002), for example, considered the Domesday Book, using the (novel) approach of a regression analysis to examine the distribution of the tax burden among certain types of communities in burden in Essex, though this type of approach is rare. However, the "research onion" process formalises much of what may be implicit or not articulated explicitly in history research. Sir John referred to the "freedom to collect material at random over along period of years, stuffing notebooks and wearing out many pencils". The conscious and unconscious assimilation of information from extensive reading over years generates ideas for research or produces research processes which are not formalised because different academic disciplines work in different ways.

\section{Conclusion}

This paper has considered various methods for researching taxation history, from the perspectives of different academic approaches - social sciences generally, law, history 
and legal history. While on the surface, approaches may appear very different, once a detailed analysis is done of what is actually going on, there is an underlying similarity between the different academic areas. The great difference is that law, history and legal history generally do not seek to analyse or justify their approaches with as much formality as the social sciences. This is perhaps because social science is conscious of borrowing its methodology and methods from pure science and that consciousness brings with it an awareness of the need to justify that borrowing in support of newer areas of study that themselves felt the need for academic validation. Law and history, however, have a longer academic history that did not perceive this need to the same degree, but which are now, perhaps, acknowledging a requirement to be more explicit about the research methods employed. 


\section{References}

Aitken, J. (2010). Powers to the Parliament, Tax Adviser, March, 12-15.

Baker, J. (2012). Reflections on 'doing' legal history. In A. Musson \& C. Stebbings (Eds.). Making Legal History: Approaches and Methodology (pp. 7-17). Cambridge: Cambridge University Press.

Black, J., \& MacCraild, D. M. (2000). Studying History (2nd ed.). Basingstoke, Hants.: Palgrave.

Bradney, A. (1998). Law as a parasitic discipline. Journal of Law and Society, 25(1), 71-84.

Cantor, N. F., \& Schneider, N. F. (1967). How to Study History. Illinois: Harlan Davidson Inc.

Chatterjee, C. (2000). Methods of Research in Law. London: Old Bailey Press.

Cohen, M. L., \& Olson, K. C. (2007). Legal Research in a Nutshell (9th ed.). St. Paul, MN: Thomson/West.

Frecknall-Hughes, J. (2014). Locke, Hume and Johnson and the continuing relevance of tax history. eJournal of Tax Research, 12(1), 87-103 (special issue in memory of John Tiley).

Frecknall-Hughes, J. (2012). Re-examining King John and Magna Carta: Reflections on Reasons, Methodology and Methods. In A. Musson \& C. Stebbings (Eds.). Making Legal History: Approaches and Methodology (pp. 244-263). Cambridge: Cambridge University Press.

Freedman, J. (2004). Taxation research as legal research. In M. Lamb, A. Lymer, J. Freedman, \& S. James (Eds.). Taxation: An Interdisciplinary Approach to Research (pp. 13-34). Oxford: Oxford University Press.

Fulbrook, M. (2002). Historical Theory. Abingdon, Oxon.: Routledge.

Gunn, S., \& Faire, L. (2012). Research Methods for History. Edinburgh: Edinburgh University Press.

Hegel, G. W. F. (1830). Lectures on the Philosophy of World History, translated by H. B. Nisbet, 1975. Cambridge: Cambridge University Press.

Knowles, J., \& Thomas, P. (2006). Effective Legal Research (1st ed). London: Thomson/Sweet \& Maxwell.

Lamb, M., Lymer, A., Freedman, J., \& James, S. (Eds.) (2004). Taxation: An Interdisciplinary Approach to Research. Oxford: Oxford University Press. 
McConville, M., \& Chui, W. H. (2007). Research Methods for Law. Edinburgh: Edinburgh University Press.

McDonald, J. (2002). Tax fairness in eleventh century England. Accounting Historians Joumal, 29(1), 173-193.

McKerchar, M. (2010). Design and Conduct of Research in Tax, Law and Accounting. Sydney: Lawbook Co., Thomson Reuters (Professional) Australia Ltd.

McKerchar, M. (2008). Philosophical paradigms, inquiry strategies and knowledge claims: Applying the principles of research design and conduct to taxation. eJournal of Tax Research, 6(1), 5-22.

Mersky, R. M., \& Dunn, D. J. (2002). Fundamentals of Legal Research (8th ed.). New York: Foundation Press.

Morris, C., \& Murphy, C. (2011). Getting a PhD in Law. Oxford and Portland Oregon: Hart Publishing.

Musson, A., \& Stebbings, C. (2012). Making Legal History: Approaches and Methodology. Cambridge: Cambridge University Press.

Oats, L. (Ed.) (2012a). Taxation: A Fieldwork Research Handbook. London and New York: Routledge.

Oats, L. (2012b). Tax research going forward. In L. Oats (Ed.) Taxation: A Fieldwork Research Handbook (pp. 242-245). London and New York: Routledge.

Pendleton, M. (2007). Non-empirical discovery in legal scholarship - choosing, researching and writing a traditional scholarly article. In M. McConville \& W. C. Chui (Eds.). Research Methods for Law (pp. 159-180). Edinburgh University Press.

Rabban, D.M. (2012). Methodology in legal history: From the history of free speech to the role of history in transatlantic legal thought. In A. Musson \& C. Stebbings (Eds.). Making Legal History: Approaches and Methodology (pp. 88-107). Cambridge: Cambridge University Press.

Rutterford, J., Maltby, J., Green, D. R., \& Owens, A. (2009). Researching shareholding and investment in England and Wales: Approaches, sources and methods. Accounting History, 14(3), 269-292.

Saunders, M., Lewis, P., \& Thornhill, A. (2009). Research Methods for Business Students (5th ed.). Harlow, Essex: Pearson Education Ltd - FT/Prentice Hall.

Saunders, M., Lewis, P., \& Thornhill, A. (2012). Research Methods for Business Students (6th ed.). Harlow, Essex: Pearson Education Ltd.

Senn, M. (2012). The methodological debates in German-speaking Europe (19601990). In A. Musson \& C. Stebbings (Eds.). Making Legal History: 
Approaches and Methodology (pp. 108-117). Cambridge: Cambridge University Press. 
Figure 1: A typical accounting route for the study of taxation

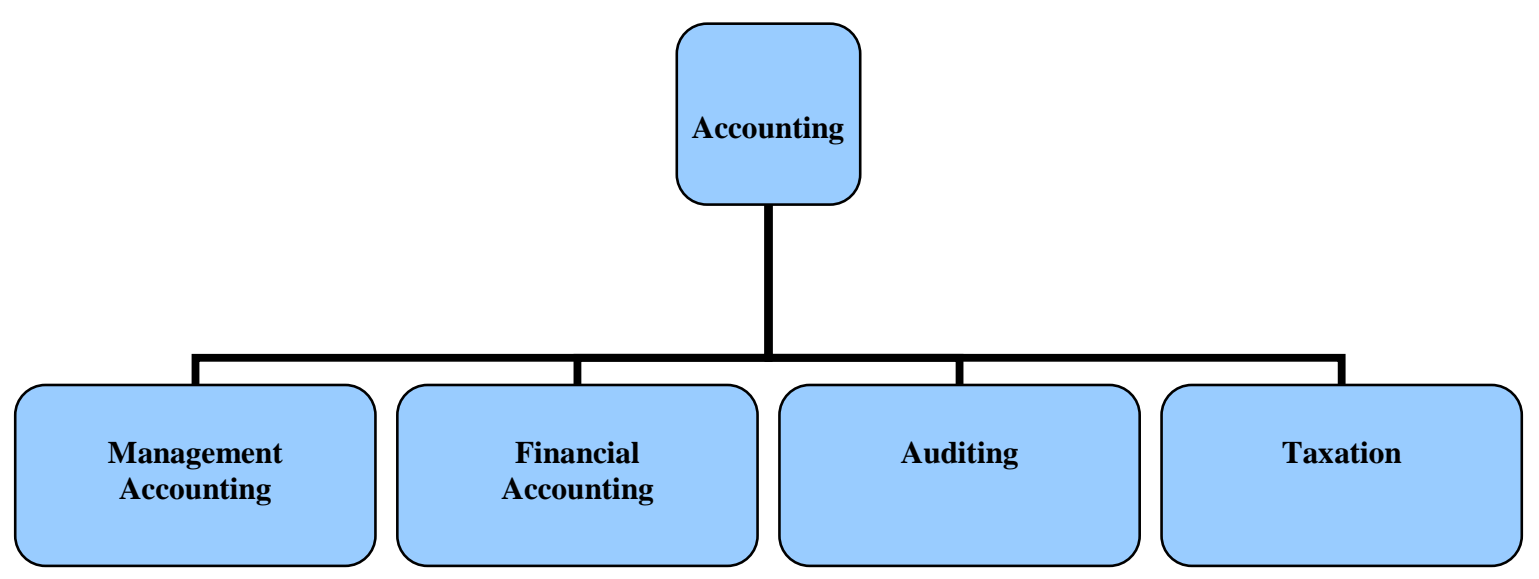


Figure 2: Taxation with a multidisciplinary and interdisciplinary focus

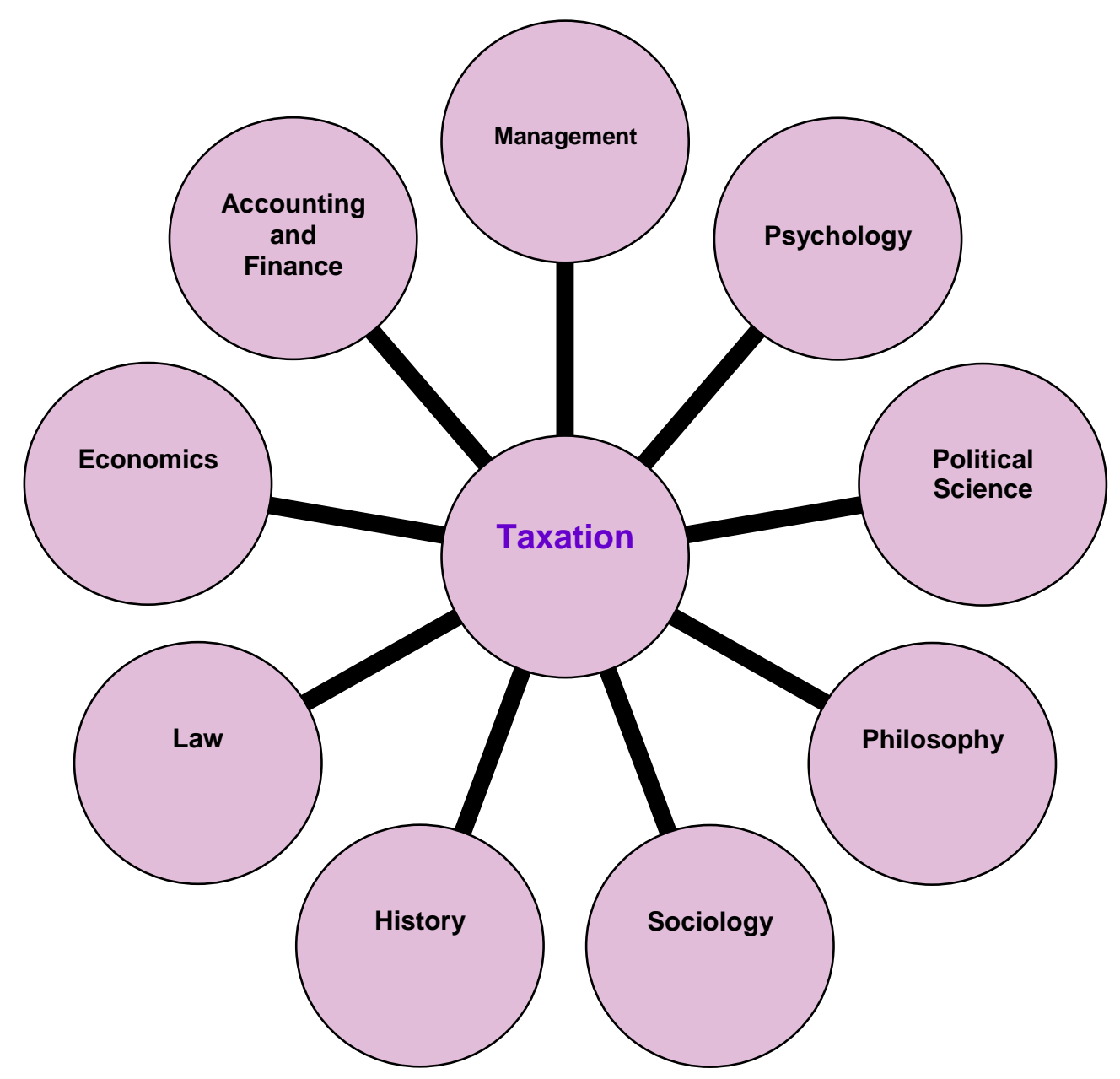


Figure 3: The research process 'onion'

(Adapted from Saunders et al., 2009, p. 108)

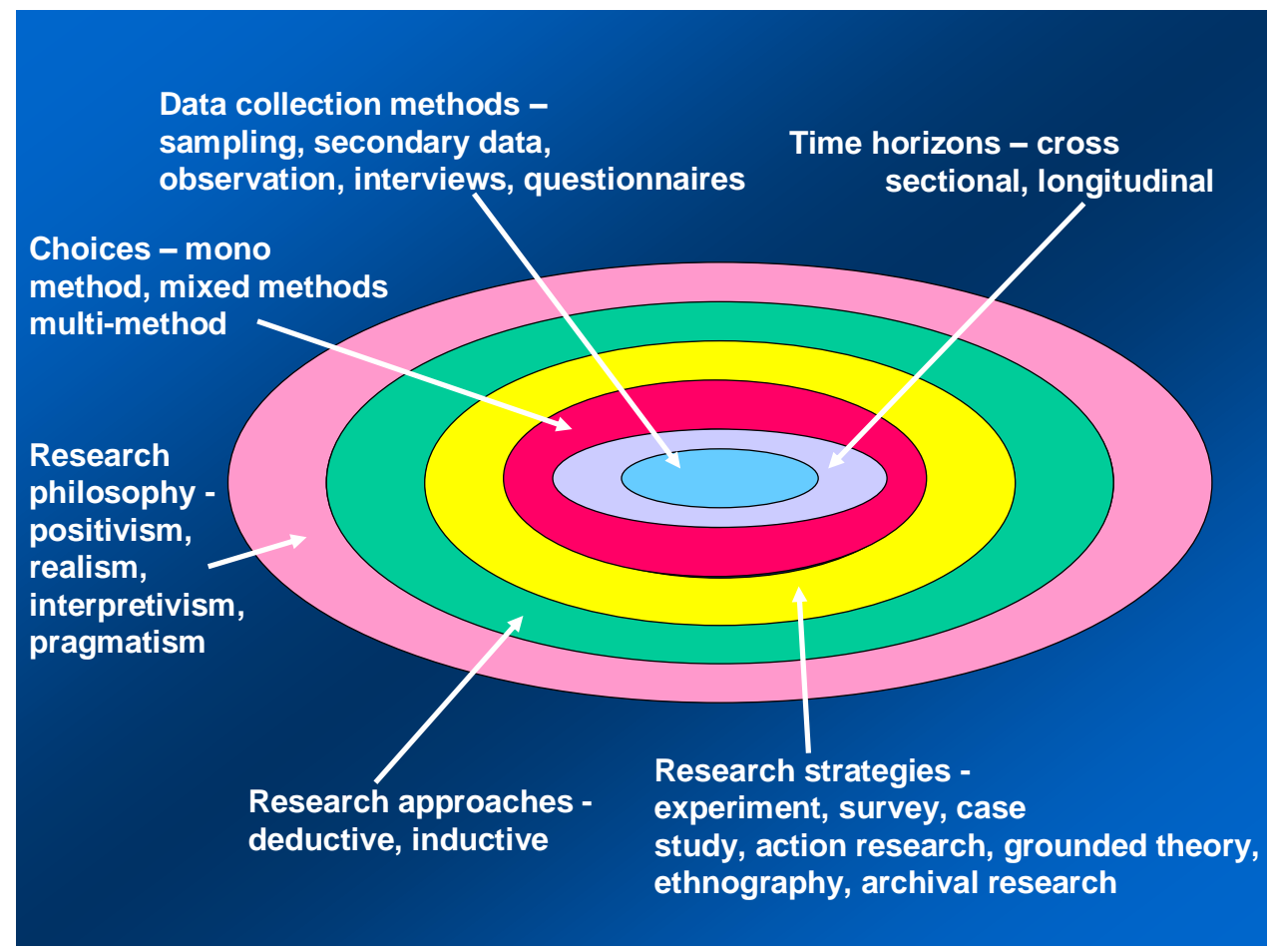


Figure 4: Taxation with a multi-layered focus using law as an example

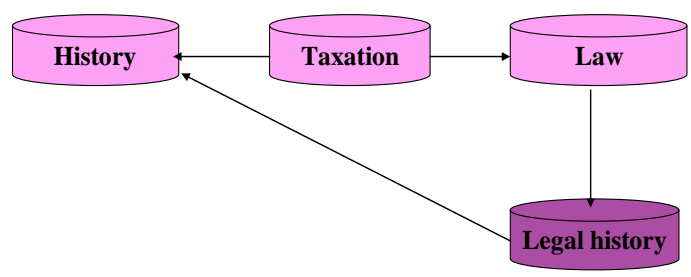

Layer 1

Layer 2 
Figure 5: Path through the "research onion", demonstrating inductive/deductive process

(Adapted from Frecknall-Hughes, 2012, p. 257)

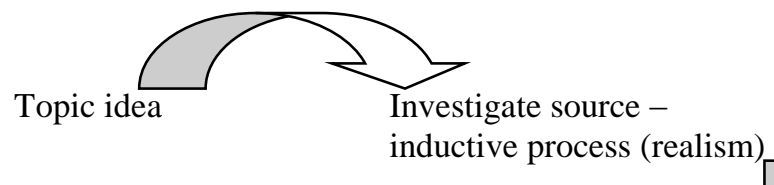

Theory 1: (baronial) tax revolt

'Deductive loops'
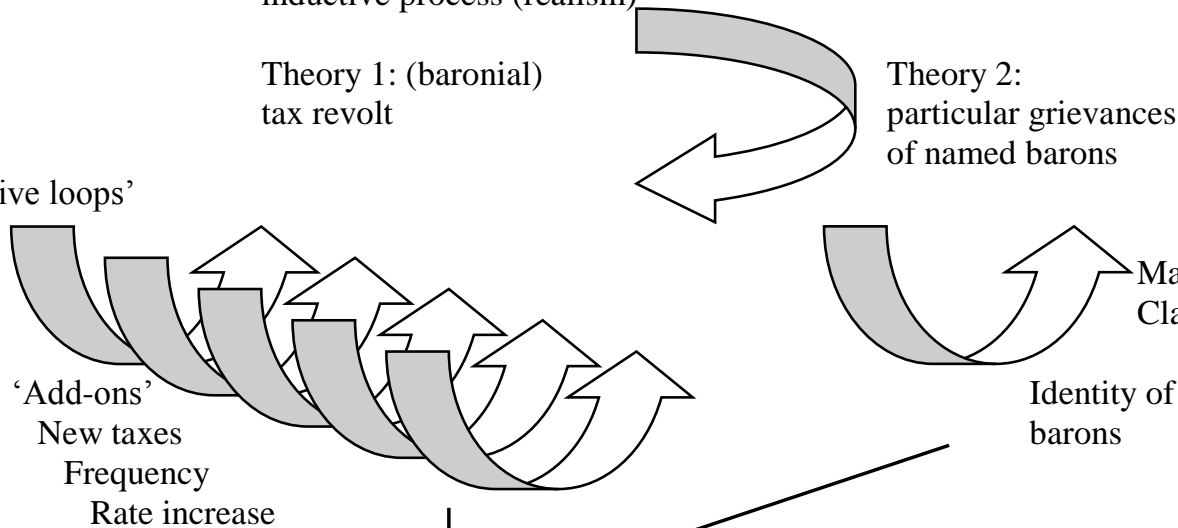

Rate increase Opportunism

Results - triangulation from multiple sources of evidence, secondary and primary

Confidence in findings 